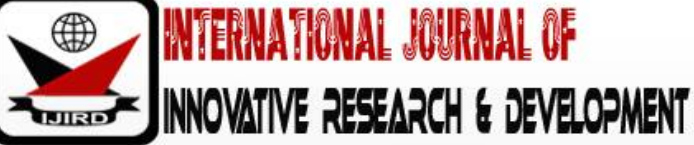

ISSN 2278 - 0211 (Online)

\section{Phyto-Chemicals of Some Plants Powder as Anti-Insects Agents against Cowpea Weevils Callosobruchus Maculatus Coleoptera: Bruchidae}

\begin{tabular}{|c|}
\hline 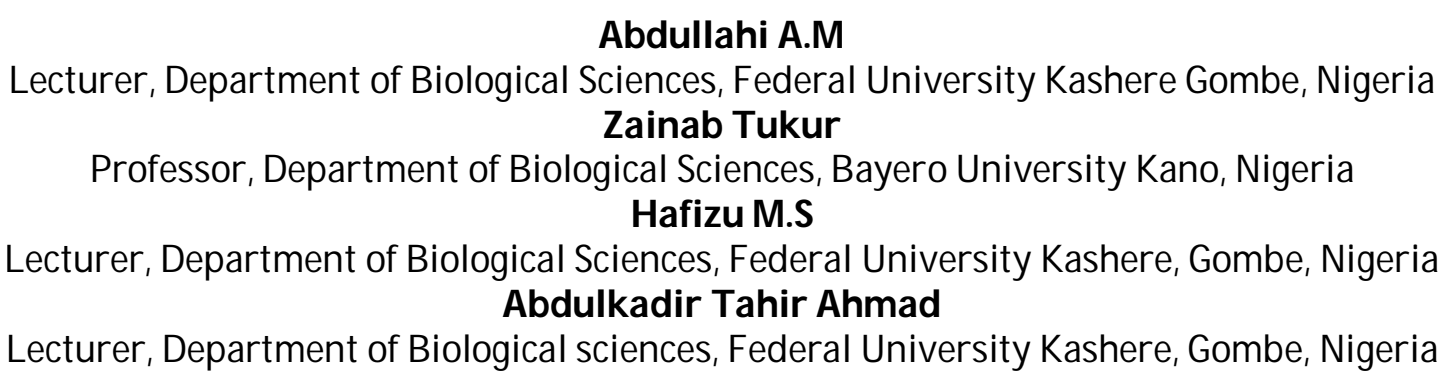 \\
\hline
\end{tabular}

\begin{abstract}
:
In this study, leaves powder of Lamium purpureum, Cyperus retrorsus, Lantana camara, Helianthus annuus, Citrus aurantifolia and Cestrum nocturnum were screened for secondary metabolite constituents and insecticidal activity against Cowpea weevils (Callosobruchus maculatus).Phytochemicals screening of the powder revealed the presence of alkaloids, terpenoids, flavonoids, tannins, saponnins, phytosteroids, phenolic compounds, proteins and aminoacids, oil and fats as well as reducing sugars in the plants investigated. Alkaloids were absent only in C. retrorsus, H. annuus and C. nocturnum, Flavonoids were absent in L .purpureum, C. retrorsus, H. snnuus and C. nocturnum, Terpenoids were absent in C. retrorsus and C. nocturnum, saponnins were absent in C. retrorsus only, Phenolic compounds were absent only in $\mathrm{H}$. annuus, Phytosterols were absent in L.purpureum, C. retrorsus and C. nocturnum. Proteins and amino acids were present only in L. purpureum and $\mathrm{H}$. annuus. Oil and fats were absent in C. retrorsus and $\mathrm{C}$. nocturnum while reducing sugars were absent in $\mathrm{L}$. purpureum, C. retrorsus and C. nocturnum. The plants powder indicates insecticidal activity in a dose dependent manner, higher doses has stronger effect, all the experimental plants caused significant mortalities $(\mathrm{p} \varangle 0.05)$ of the C. maculatus. $L D_{50}$ (g) showed thatH. annuus (6.2)andC nocturnum (6.2) were most toxic to C. maculatus than L. purpureum (9.7), C. aurantifolia (12.8) andL. camara (12.8) were more toxic than C. retrorsus (18.2) which was least toxic to adults of C. maculatus. Therefore, these phytochemical constituents of plants powder have potential to be used as control agents of $\mathrm{C}$. maculatus infestations and could be use as replacement or supplements to conventional chemical insecticides which price, availability and technology of applications may be out of reach to poor farmers.
\end{abstract}

Keywords: Powder, phyto-chemical, screening, insecticidal activity, callosobruchus maculatus

\section{Introduction}

Cowpea weevil Callosobruchus maculatus is an agent of massive destruction causing the major lost in stored cowpea worldwide. Infestation of C. maculatus can be up to $90 \%$ in markets and village stores (Ofuya, 2010). In West Africa up to $100 \%$ damage to stored cowpea by C. maculatus may occur in just few months of storage (Maina, 2012). Besides storage, infestation can also occur from field which significantly reduces the quantity and quality of seeds reserved for sowing, food and trading purposes (Lale \& Ofuya, 2001). Cowpea is usually treated with chemical insecticides before storage, to prevent infestation by destructive insects such as C. maculatus. Chemical insecticides; however, are restricted because of the development of pest resistance, health hazards and risk of environmental contamination (Isman, 2006). C. maculatus ability to resist chemical insecticides such as dichlovors (DDVP) has been reported (Olajire et al., 2016); in addition several deaths have been reported to consumption of cowpea treated with chemical insecticides for storage (FAO, 2010).Stored-product pest management in most part of the world has relied on the use of chemical insecticides; however, chemical control methods are restricted because of the development of pest resistance, health hazards and risk of environmental contamination (Isman, 2006). Therefore, in the current scenario, there is urgent need to develop safer, environmental friendlier and efficient alternatives that have potential to replace synthetic chemical insecticides and convenient to use. Plants powders and their components have shown to possess potential for development as insecticides and they may have advantages over conventional insecticides in terms of low mammalian toxicity, rapid degradation and local availability (Liys et al., 2001). Phytochemical compounds such as Alkaloids, Terpenoids, Flavonoids, Tannins, Saponins and Phenolic compounds are reported to possess anti-insects activities (FAO, 1999). The presence of these compounds forms the basis of the insecticidal properties of the plants powder and extracts. These compounds can affect 
insects in several different ways: they may disrupt major metabolic pathways and caused rapid death (Bell et al., 1990) acts as attractants, deterrents, phagostimulants, antifeedants or modify ovipositions, retard or accelerate development or interfere with life cycle of the insects in other ways (Bell et al., 1990). Hence in the present study, powder phytochemical constituents of six (6) different plants species were evaluated for anti-insects properties against Cowpea weevils Callosobruchus maculatus.

\section{Material and Method}

\subsection{Culturing of Insects}

Cowpea weevils Callosobruchus maculates were collected from infested stock of cowpea at A. Rimi market Kano. C. maculatuswas identified as describe byRahman and Talukder(2006) Twenty (20) pairs of C. maculatus were used to infest fresh preserved $1000 \mathrm{~g}$ of cowpea contained in a labeled transparent bucket (35 cm height and $30 \mathrm{~cm}$ diameter). The bucket was capped with piece of net $10 \mathrm{mesh} / \mathrm{cm}$ which allowed for ventilation but preclude the entry or exit of the insects. The set were maintain under ambient conditions of temperature, relative humidity and photoperiods $\left(32 \pm 0.64{ }^{\circ} \mathrm{C}, 68 \pm 3 \%\right.$ and 12L: 12D) (Olaifa et al., 1997) in the Laboratory for two weeks to ensure oviposition. The parent stocks were sieve out and maintained undisturbed until adult emergence. The First Filial (F1) adults emerging over 24hrs period were collected, preserved in another container and used for subsequent experiments (Magaji et al., 2009).

\subsection{Collection of Plant Materials and Powder Preparation}

The six (6) plants materials were collected around Sharada phase II industrial area Kano by direct hand picking and identified at herbarium of the Department of Biological Science Bayero university Kano. The plants were washed with clean water and dried under shade at room temperature of about $30^{\circ} \mathrm{C}$ for five days. Shade dried Materials of each of the six (6)were grounded into fine powder using mortar and pestle as describe by Lale (2002). Four different dosages (1 $\mathrm{g}, 2 \mathrm{~g}$, $3 \mathrm{~g}$, and $4 \mathrm{~g}$ ) of each of the plants powder were prepared using weighing balanced.

\subsection{Phytochemical Screenings}

All the six (6) plant used in this research were screened for the presences of the following commonly found plants secondary metabolites.

- 1-Alkaloids.

- 2-Flavonoids.

6-Saponins.

- 3-Terpenoids.

7-Tannins.

- 4-Oils and Fats.

8-Proteins and Amino acids.

9-Phenolic Compounds.

- 5-Reducing Sugars. 10-Phytosterols.

\subsubsection{Alkaloids}

Drops (2-3) of Dragendoff's reagent were added to $1 \mathrm{ml}$ of the powder solution (Aqueous). An orange red precipitation indicates the presence of alkaloids (Ciulci, 1994).

\subsubsection{Flavonoids}

Two milliliter $(2 \mathrm{ml})$ of each of powder solution (aq) were dissolved in Sodium hydroxide Solution $\left(\mathrm{NaOH}_{\text {(aq) }}\right)$ Yellow solution appeared which disappears on addition of Hydrochloric acids indicates the presence of Flavonoids (Onyeleke and Manga, 2008).

\subsubsection{Terpenoids}

Two milliliter (2ml) of Chloroform were mixed with powder Solution (aq) then followed by addition of 3ml of Sulphuric acid $\left(\mathrm{H}_{2} \mathrm{SO}_{4(\mathrm{aq})}\right)$. Formation of reddish brown color indicates the presence of Terpenoids (AbdulWadood et al., 2013)

\subsubsection{Oils and Fats}

A small quantity of powder solution was compressed in between two filter papers. Oil stains on the filter paper indicate the presence of oils and fats (Kalita et al., 2011)

\subsubsection{Reducing Sugars}

Powder solution (aq) in a test tube was added with few drops of Fehling's A and B solution. The mixture was warmed. Brick red precipitate at the bottom of the test tubes indicates the presence of reducing sugar (Brain and Turner, 1975)

\subsubsection{Saponins}

Five milliliter ( $5 \mathrm{ml}$ ) of distilled water was added into $1 \mathrm{ml}$ of powders solution (aq) in test tubes the mixture was shaken vigorously. A persistent froth that lasted for 15minutes indicates the presence of Saponins (Brain and Turner, 1975) 


\subsubsection{Tannins}

Two milliliter ( $2 \mathrm{ml}$ ) of each plant powders solution (aq) was added with 2-3 drops of $5 \%$ ferric chloride ( $\mathrm{FeCl}_{3(\mathrm{aq}))}$ Solution in test tubes. A green-black coloration indicated the presence of Tannins (Ciulci, 1994)

\subsubsection{Proteins and Amino Acids}

Each plant powder solutions(aq) were mixed with few $\mathrm{ml}$ of $\mathrm{HCl}_{(\mathrm{aq})}$ then followed by 2 drops of ninhydrin solutions (10mg of ninhydrin in $200 \mathrm{ml}$ of acetone) in a test tubes the mixture was shaken thoroughly, purple coloration indicates the presence of protein and Amino acids.(Kalita et al., 2011).

\subsubsection{Phenolic Compounds}

Each plants powder solution (aq) in test tubes was added with few drops of neutral 5\% Ferric chloride $\left(\mathrm{FeCl}_{3}\right)$ Solution. A dark green color indicates the presence of Phenolic Compounds. (Kalita et al., 2011)

\subsubsection{Phytosterols}

Each plants powder solution (aq) were dissolved in a $2 \mathrm{ml}$ of acetic anhydride, then followed by conc. $\mathrm{H}_{2} \mathrm{SO}_{4}$ (aq) added slowly along the sides of the test tubes. An array of color changes showed the presence of phytosterols (Kalita et al., 2011).

\subsection{Powder Toxicity Assay}

Method used by Abdullahi et al. (2010) were adopted, four different concentrations of all the six (6) plants powders $(1 \mathrm{~g}, 2 \mathrm{~g}, 3 \mathrm{~g}$ and $4 \mathrm{~g}$ ) were admixed with $10 \mathrm{~g}$ each of preserved cowpea contained in a small transparent plastic containers ( $4 \mathrm{~cm}$ height and $6 \mathrm{~cm}$ diameter) with control treatments having no plants powders.

Ten (10) adults (5-14 days old) of C. maculates were introduced into treated and untreated cowpea and then closed with perforated cap to aid ventilation but preclude the entry or exits of the insect pests. Insects' mortality was scored at $24 \mathrm{hrs}$ post-treatment intervals for one week. Insects were considered dead only if they fail three probing blunt test and Abbotts formula (Abbott, 1925) was used to correct observed mortalities where control mortalities exceed 20\%.

Correct Mortality $=$ \%Test Mortality $-\%$ Control Mortality $\times 100$

$$
100 \text { - \%Control Mortality }
$$

\subsection{Data Analysis}

All data generated from the experiments were subjected to analysis of variance (ANOVA) using SPSS (version 20) for windows, means were separated $\left(\mathrm{p}<0.05\right.$ ) using Turkeys tests, while $\mathrm{LD}_{50}(\mathrm{~g})$ values for powder were also estimated by Probits analysis using same statistical packaged.

\section{Results and Discussion}

3.1. Phytochemical constituents of plants powder

The phytochemical compounds were identified by preliminary phytochemical screening and the results obtained were presented in Table 1

\begin{tabular}{|c|c|c|c|c|c|c|}
\hline Test & L.purpureum & C.retrorsusL & camara & annuus & C.aurantifolia & C.nocturnum \\
\hline Alkaloids & + & - & + & - & + & - \\
Flavonoids & - & - & + & - & + & - \\
Terpenoids & + & + & + & - & + & - \\
Saponnin. & + & - & + & + & + & + \\
Tannin. & + & + & + & + & + & + \\
PC & + & + & + & - & + & + \\
Phytosterols. & - & - & + & + & + & - \\
PAA. & + & - & - & + & - & - \\
OAF & + & - & + & + & + & - \\
RS & - & - & + & + & + & + \\
\hline
\end{tabular}

Table 1: Phytochemical Constituents of Powder of the 6 Experimental Plants

$*$ Key $+=$ Presence, $-=$ Absence, $\mathrm{PC}=$ Phenolic Compounds, PAA =Protein And Amino Acids, $\mathrm{OAF}=$ Oils and Fats, $\mathrm{RS}=$ Reducing Sugars,

Alkaloids was found in powder of L. purpureum, L. camara and C. aurantifolia, also Flavonoids was detected in the powder of L. camara and C. aurantifolia only, Similarly Tannins was identified in powder of all the six (6) plants, the same with Saponins which is only absent in powder of C. retrorsus.

Phenolic compound was not found in the powder of $\mathrm{H}$. annuus but found in all other plants powder screened, Phytosterol was detected only in powder of L. camara, H. annuus and C. aurantifolia, but protein and Amino acids were found in powder of L. purpureum and H. annuus respectively. Oils and Fats were found in powder of L. purpureum, L. camara, $\mathrm{H}$. annuus and C. aurantifolia. While reducing sugars were found in powder and of $\mathrm{H}$. annuus, C. aurantifolia and powder of L. camara. 


\subsection{Powder Toxicity}

For all the plants powder used, the percentage mortality increased with increased in dosage levels of the plants powders for $\mathrm{C}$. maculatus, the effects indicate by different levels of dosage of plants powder used on the percentage mortality of adults $\mathrm{C}$. maculates were presented in Table 2 . While the results of Probits analysis indicating $\mathrm{LD}_{50}(\mathrm{~g})$ of the experimental plants used against C. maculatus, were presented in Table 3.

\begin{tabular}{|c|c|c|c|c|c|}
\hline \multicolumn{7}{|c|}{ Powder Amount (G) In 10g Of Beans (C.Maculatus) } \\
\hline Plant Used & Control & 1.00 & 2.00 & 3.00 & 4.00 \\
\hline L.Purpureum & $19.2 \pm 1.0 \mathrm{a}$. & $71.4 \pm 0.6 \mathrm{a}$. & $64.2 \pm 0.4 \mathrm{a}$. & $80.2 \pm 0.6 \mathrm{~b}$. & $82.4 \pm 0.6 \mathrm{c}$. \\
C.Restrorsus & $16.6 \pm 1.2 \mathrm{~b}$. & $32.4 \pm 1.0 \mathrm{e}$. & $51.7 \pm 0.5 \mathrm{~b}$. & $61.0 \pm 0.4 \mathrm{c}$. & $83.4 \pm 0.6 \mathrm{~b}$ \\
L.Camara & $20.0 \pm 1.0 \mathrm{a}$. & $54.1 \pm 0.5 \mathrm{~b}$. & $63.2 \pm 0.4 \mathrm{a}$. & $78.1 \pm 0.6 \mathrm{c}$. & $87.1 \pm 0.6 \mathrm{~b}$. \\
H.Annuus & $8.7 \pm 1.3 \mathrm{c}$. & $44.1 \pm 0.7 \mathrm{~d}$. & $64.2 \pm 0.4 \mathrm{a}$. & $76.1 \pm 0.6 \mathrm{c}$. & $86.2 \pm 0.6 \mathrm{~b}$. \\
C.Aurantifolia & $9.1 \pm 1.3 \mathrm{c}$. & $47.2 \pm 0.7 \mathrm{c}$. & $65.0 \pm 0.4 \mathrm{a}$. & $86.2 \pm 0.6 \mathrm{a}$. & $94.1 \pm 0.8 \mathrm{a}$. \\
C.Nocturnum & $20.0 \pm 1.0 \mathrm{a}$. & $31.6 \pm 1.0 \mathrm{f}$. & $41.2 \pm 0.7 \mathrm{~b}$. & $53.6 \pm 0.5 \mathrm{~d}$. & $68.3 \pm 0.4 \mathrm{~d}$. \\
\hline
\end{tabular}

Table 2: Percentage Mortality (\%) of Adult Insects Treated with

Powder of Experimental Plants at 96hrs Post Exposure

Each value is the mean ( $\pm \mathrm{SE}$ ) of three replicate. Means in each column by same alphabet(s) are not significantly different $(p<0.05)$ by Turkey's tests.

\begin{tabular}{|c|c|c|c|}
\hline Plant Used & LD50(g) & df & Chi2 \\
\hline L.purpureum & 9.65 & 5 & 0.307 \\
C.restrorsus & 18.1 & 5 & 0.150 \\
L.camara & 12.81 & 5 & 0.120 \\
H.annuus & 6.17 & 5 & 0.977 \\
C.aurantifolia & 12.81 & 5 & 0.120 \\
C.nocturnum & 6.17 & 5 & 0.977 \\
\hline
\end{tabular}

Table 3: $\left.\mathrm{LD}_{50}(\mathrm{G})\right)$ f Experimental Plants Powder against C. Maculates

Out of the six (6) plant species screened, L. camara and $C$.aurantifolia possess the highest number of phytochemical compounds nine (9), L. camara has eight (8), L. purpureum seven (7) compounds are found, H. annuus that has six (6) phytochemical compounds in its powder. The least number of phytochemical compounds (3) was found in powder of C. retrorsus and C. nocturnum. Hence insecticidal activities indicated by L. purpureum, C. retrorsus, L. camara, H. annuus, C. aurantifolia and C. nocturnum could be attributed to the compositions of these compounds in their powder. $\mathrm{LD}_{50}(\mathrm{~g})$ estimated, showed thatH. annuus (6.2)andC nocturnum (6.2) were most toxic to C. maculatus thanL. purpureum (9.7), C. aurantifolia (12.8) andL. camara (12.8) were more toxic than C. retrorsus (18.2) which was least toxic to adults of C. maculatus(Table 3).

The results of analysis of variance (ANOVA) indicates that all levels of dosages of plants powder used have significant powder toxicity against C. maculatus, Hence the results of post-experimental comparisons (Turkey's Tests) Showed that, C. maculatuswas susceptible to all plants powder treatment with highest mortality (94.1\%) observed in C. aurantifolia treatments at dosage level $4.0 \mathrm{~g} 96 \mathrm{hrs}$ post-treatments intervals (Table 2), however, all the plants powder treatments at all dosage levels used indicate significant powder toxicity to C. maculatus, when compared with controls $(\mathrm{p}<0.05)$ (Table 2).

The mortality caused by the phytochemical constituents of plants powder could be attributed to several mechanisms (Odeneyi et al., 2000), the plants powder could have resulted to death of the insects due to contact poisoning, interference with acetylcholine receptors (Rattan, 2010), ingestions of the powder constituents which may in turn interfere with metabolic activities of the insects causing rapid death (Bell et al., 1990) blockage of spiracles or interference with cuticular development of the insect pest as a results of direct contact between the insects and plants powder (Abdullahi et al., 2010). The differences in anti-insects properties of the experimental plants powder could be due to the differences in compositions of the active compounds or phytochemicals in their powders.

These results were in agreement with many other works on the use of plant powders against stored products insects' pests.Ajayi (2013) reported that powder and extracts of Delonix regia seeds were effective in controlling Cowpea weevils Callosobruchus maculatus. Results of findings of Awoke et al, (2014) showed that leaves powders of Melia azedarach, Mentha piperita and Schinus molle were effective in controlling C. maculatus. Olaifa and Erhun (1988); Fasakin and Aberejo (2002) Observed that Piper guineese spice powder prevent oviposition on Callosobruchus maculatus and Dermestes maculatus respectively, and therefore, reducing the longevity of the insects. Similarly, Abdullahi et al., (2010) reported that Citrus peel powder was effective in suppressing the survival of T. castaneum when applied at 4, 6 and $8 \mathrm{~g}$ respectively. Furthermore, Akinkurolere (2012) reported that plants powders of Tetrapleura tetraptera, Monodora myristica and Momordica charantia were found to be effective in controlling Cowpea weevils' C. maculatus. Bernard and Daniel (2013) reported that Basil plant powder (Ocimun basilicum) were only effective for short durations as protectants against Maize weevils S. zeamais. Popoola (2013) also reported those powders and whole forms of Allium sativum, Allium cepa and Capsicum annum to cause significant mortality and reduction in F1 adults' emergence of Oryzaephilus dutinamrnsis infesting Date fruits. Similarly, Aswalam and Onu (2014) recorded the effectiveness of plants powder 
prepared from different parts of A. sativum, Zingiber officinale, Curcuma longa, Ficus exasperata and Garcinia kola in killing and Controlling of Trogoderma granarium in stored groundnut.

The phytochemicals or secondary metabolites such as alkaloids, terpenoids, flavonoids, tannins, saponnins and phenolic compounds present in the powder of L. purpureum, C. retrorsus, L. camara, H. annuus, C. aurantifolia and C. nocturnum were responsible for the anti-insects properties indicated by their powders, hence these compounds can be developed as a replacement or supplement to most widely used synthetic pesticides which; price, availability and technology of applications may be out of reach to poor farmers, as well as its effect to the environment, man and livestock and also the development of resistance by the insect pests.

\section{Reference}

i. Abdullahi, N. A. Muhammed, and ZTukur, (2010) Assessment of citrus peel powder against Tribolium castaneum (Coleoptera: Tenebionidae) infesting stored products. Bioscience Research Communications 22(5): 283-286.

ii. Abdulwadood, Mehreen, G. Syed, B.J. Muhammad, N. Ajmal, K. Rukhsana, G. and Asnad (2013) Phytochemical analysis of Medicinal plants occurring in Local Area of Mardan, Biochem. Anal.Biochem. 2:144.

iii. Abott, W.S. (1925) A Method of Computing the Effectiveness of an Insecticides. Journal of Economic Entomology 18:265-266.

iv. Ajayi, O.E. (2013) Insecticidal activity of powder and extracts of Delonix regia seed against maize weevil, Sitophilus zeamais (Coleoptera: Curculionodae). Futa Journal of Research in Sciences 1: 54-62.

v. Akinkurolere, R.O. (2012 ) Comparative effects of three plants powders and pirimiphos-methyl against the infestation of Callosobruchus maculatus (F) (Coleoptera: Bruchidae) in cowpea seeds. Signpost Open Access Journal of Entomological studies 1(2): 108-117.

vi. Asawalam, E.F. and Oni, L. (2014) Evaluation of some plant's powders against Khapra beetle (Trogoderma granium) (Coleptera: Dermestidae) on stored groundnut. Advancement in medicinal plant Research. 2(2): 27-33.

vii. Awoke, Y. Gerut, A. Gatachev, M. Mulugeta, D. Sirgota, K. and Nagappan, R. (2014) Evaluation of certain plants leaf powders and aqueous extracts against maize weevil, Sitophilus zeimais (Mostch) (Copeoptera: Curculionidae) Asian Journal of Agricultural Sciences. 6(3): 83-88.

viii. Bell, A.E. Fellows, L.E. and Patil, B.D. (1985) Evaluation of some plants extracts as protectants against the pulse beetle (Callosobruchus maculatus) (F) infesting cowpea seeds.J.Ento.Research. 2(2): 183-187.

ix. Bergvinson, D. (2004). Reducing Damage to Grain Stores of the Poor. From http:/ / www.cimmyt.org/ news/ 2004/ . Retrieved December 03, 2017.

x. Bernard, M.M. and Daniel, L.M. (2013) Performance of Basil powder as insecticide against maize weevil S.zeimais (Coleoptera: Curculionidae). Discourse Journal of Agriculture and Food Science. 1(1): 196-201.

xi. Bousquet, Y. (1991) Beetles associated with stored-products in Canada. An identification guide. Research Branch of Agriculture Canada publication, 5:1830-1855.

xii. Brain, K.R. and Turner, T.D. (1975). The practical evaluations of phytopharmaceuticals. Wright Scientechiea. Bristol 1: 57-58.

xiii. Ciulci, I. (1994) Methodology for the analysis of vegetables drugs Chemical Industries branch, Division of Industrial Operations. UNIDO. Romania.

xiv. Fasakin, E.A. and Aberejo, B. (2002) Effects of some pulvurized plants materials on the developmental stages of Fish beetles (D. Maculatus) Degeer in smoked catfish (Ckarias graepinus) during storage Bio.Sci. Technol. 85: 173177.

xv. FAO, (1999) The use of spices and medicinal as bioactive protectants for grain by Golob P, Caroline M, Dales M, Alex F and Jenny E. Agricultural Services Bulletins, 137.

xvi. F.A.O, Food and Agricultural Organisation. (2002). Assesment of the World Food Security

xvii. Situation. Committee on the World Food Security, 28th session, Rome. http:// www.fao.org/ docrep/ meeting/ 004/ y6441e/ y6441e00.htm\#. Retrieved December 03, 2017

xviii. FAO (2010) Assuring Food Safety and Quality: Guidelines for Strengthening National Food Control System, FAO Food and Nutrition Paper 76, FAO/ WHO, Rome.

xix. Gerald, N. (2008). Maize weevils. Daily Times paper, Malawi's Premier Daily. 28 May 2008

xx. Isman, M.B. (2006) Botanical insecticides, deterents and repellents in modern agriculture and an increasingly regulated world. Annual Review Entomology 51:45-66

xxi. Kalita, S. Kumar, G. Karthik, L. and Rao, K.V.B. (200) Phytochemical compositions and in vitro Hemolytic activity of Lantana camara L (Verbenaceae) Leaves. Pharmacologyonline. 1: 59-67.

xxii. Lale, N.E.S. (2002) Stored Products Entomology and Acarology in Tropical Africa. Mole publications. pp204

xxiii. Lale, N.E.S. and Ofuya, T.T. (2001). Pest of stored ceeals and pulses in Nigeria; Biology, Economy and control. Akure: Dave Collins Publications

xxiv. Liys, Zouh. H.Y. (2001) Insecticidal activity of extracts from Eupatotrium adenophorum against four stored-grain insects. Entomological Knowledge, 38:214-216

xxv. Magaji, B.T. Dike, M.C. and Amatobi, C.I. (2009) Effect of an essential oil extracted from leaves of Eucalyptus Camaldulensis and Neem seed oil as stored cowpea protectant against Callosobruchus maculatus infestations. BEST Journal 6(2):53-56.

xxvi. Maina, Y.T., Mbaya, A.M. and Mailafia, D.M. (2012). Susceptibility of six local and four improved cowpea cultivars to Callosobruchus maculatus (F.) (Coleoptera: Bruchidae) infestation in north eastern Nigeria. Journal of Environmental Issues and Agriculturein Developing Countries. 4(1): 31-35 
xxvii. Ofuya, T.I., Olotuah O.F. and Akinyoade, D.O. (2010). The effect of storage on the efficacy of Eugenia aromatic (Baill.) in the control of Callosobruchus maculatus (Fabricius) (Coleoptera: Bruchidae) pest. J. Appl. Sci. Environ. Manage. 14(1): $97-100$

xxviii. Oleifa, J.I. and W.O. Erhun, (1998) Laboratory evaluation of Piper guineese for the protection of cowpea against C.maculatus insects. Sci.Applic. 9: 55-59.

xxix. Onyeleke, S.B. and Manga, B.S. (2008) Essentials of Laboratory practical in Microbiology 1st Edition. Tobest Publishers pp94.

xxx. Popoola, K.O.K. (2013) Application of Selected Bioinsecticides in management of Oryzaephilus surinamensis (Coleoptera: Silvaridae) on Phoenix daetactylifera (Date Fruits). Nature and Science. 1(1): 110-115.

xxxi. Rahman A and Talukder F A, (2006) Bioefficacy of some plant derivatives that protect grains Against the pulse beetle. Callosobruchus maculatus. Journal of Insect Science 6:3-10.

xxxii. Rattan, R.S. (2010) Mechanism of action of insecticidal secondary metabolites of plants origin, crop protection 29: 913-920. 